ISSN 1979-7450

\title{
STUDI KELAYAKAN BENDUNGAN REMU KOTA SORONG
}

\author{
Hendrik Pristianto \\ Mahasiswa Program Magister Teknik Sipil Keairan Universitas Hasanuddin Makassar \\ Fakultas Teknik Universitas Al-Amin Muhammadiyah Sorong
}

\begin{abstract}
Abstrak
Dalam rangka pengendalian banjir di sekitar daerah aliran sungai remu, dan untuk mensuplai kebutuhan air bersih masyarakat Kota Sorong, Pemerintah Kota Sorong menyusun rencana pembangunan bendungan Sungai Remu sebagaimana tertuang dalam RTRW Kota Sorong Tahun 2007-2012. Dari hasil analisa terhadap rencana tersebut, dibandingkan dengan dua alternatif lain, disimpulkan bahwa rencana bangunan bendungan tersebut layak untuk dilaksanakan akan tetapi biaya konstruksinya yang besar. Sebagai alternatif yang direkomendasikan adalah pembanguan dam seri, atau bendung yang dibangun di beberapa lokasi sepanjang aliran sungai Remu untuk mereduksi kuantitas debit, energy dan kecepatan aliran banjir.
\end{abstract}

Kata Kunci : Sungai, Bendungan, Dam

\section{PENDAHULUAN}

\subsection{Latar Belakang}

Permasalahan pengelolaan sumber daya air di Kota Sorong perlu mendapatkan penanganan yang serius, hal ini dikarenakan terjadinya krisis air bersih dan banjir pada saat yang hampir bersamaan. Secara hidrologi, kondisi Kota Sorong mempunyai curah hujan yang tinggi sepanjang tahun, sehingga memungkinkan untuk dikelola sedemikian rupa dalam rangka pemenuhan kebutuhan air bersih dan metode pengendaian banjir yang sesuai.

Sungai Remu merupakan potensi sumber daya air dari Kota Sorong, akan tetapi sampai saat ini belum ada penanganan yang terintregrasi dari hulu sampai hilir. Dalam Rencana Tata Ruang Wilayah (RTRW) Kota Sorong Tahun 2007-2012, tercantum adanya rencana pengembangan daerah hulu sungai Remu untuk dibangun sebuah bendungan. Rencana ini perlu didukung, akan tetapi juga harus dilakukan kajian secara teknis untuk memastikan nilai manfaatnya apakah sebanding dengan nilai investasi yang akan dikeluarkan.

\subsection{Ruang Lingkup}

Ruang lingkup dalam penulisan makalah ini adalah sebagai berikut :
1. Mengkaji kelayakan rencana pembangunan Bendungan Sungai Remu.

2. Desain / planning yang dikaji adalah rencana Pemerintah Kota Sorong seperti yang tertuang dalam bab 4 RTRW Kota Sorong Tahun 2007-2012, sub bab 4.4 . Rencana Pengembangan Bendungan Sungai Remu

3. Menyusun rekomendasi bagi pihakpihak terkait tentang rencana tersebut

\subsection{Maksud dan Tujuan}

Maksud dari penulisan makalah ini adalah untuk mengetahui kelayakan rencana pengembangan kawasan hulu daerah aliran sungai (DAS) Remu dengan pembangunan bendungan dan fasilitas-fasiltas pendukungnya seperti yang tercantum dalam Rencana Tata Ruang Wilayah (RTRW) Kota Sorong Tahun 2007-2012.

Adapun tujuanya adalah sebagai referensi awal untuk menyusun studi kelayakan yang lebih komprehensif terhadap rencana pengembangan DAS Remu khususnya dalam kaitannya untuk upaya pemenuhan kebutuhan air bersih dan pengendalian banjir di wilayah Kota Sorong. 


\section{METODOLOGI}

Metodologi dalam penyusunan makalah ini :

1. Melakukan analisa kondisi topografi DAS Remu dari Peta Rupa Bumi Kota Sorng

2. Melakukan analisa kondisi hidrometri DAS Remu

3. Melakukan estimasi letak site Bendungan Sungai Remu dengan tujuan utama pembangunan adalah untuk pengendalian banjir dan pemenuhan kebutuhan air bersih.

\section{ANALISA DATA}

\subsection{Analisa Kondisi Topografi DAS Remu}

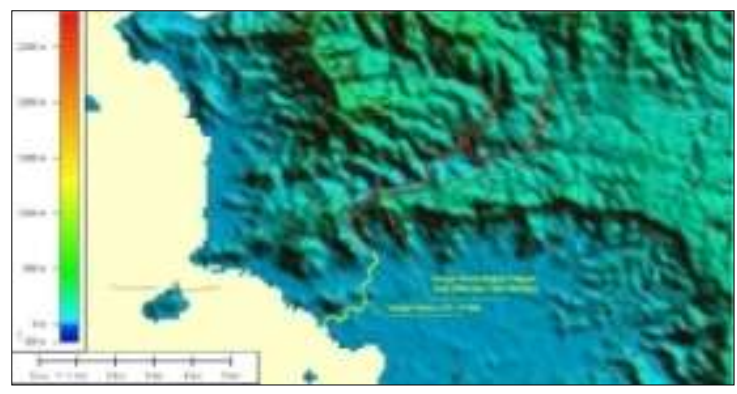

Gambar 1. Peta Rupa Bumi DAS Remu

Sumber peta rupa bumi DAS Remu Sorong: http://hypersphere.telascience.org/elevation/ cgiar_srtm_v4/ascii/zip/srtm_63_13.ZIP, kemudian diolah dengan software global mapper untuk memunculkan garis kontur elevasi muka tanahnya.

Dari gambar 1. di atas dapat kita deskripsikan sebagai berikut :

1. Peta Rupa Bumi yang ditampilkan memakai skala 1 : 260.000, dengan interval kontur yang dihasilkan adalah 20 meter

2. Kondisi topografi Kota Sorong secara umum adalah kota pesisir yang berada di depan gugusan bukit yang tingginya berkisar antara 140 sampai 600 meter di atas permukaan air laut.

3. Daerah aliran sungai (DAS) Remu merupakan salah satu sungai di Kota Sorong yang posisinya membelah kota Sorong.

4. Panjang total sungai Remu sekitar 14,7 $\mathrm{km}$, dengan rincian : panjang sungai utama $11,7 \mathrm{~km}$ dan panjang anak-anak sungai di daerah hulu $3 \mathrm{~km}$.

5. Luas Daerah Aliran Sungai Remu adalah sekitar $250 \mathrm{~km}^{2}$

6. Sungai yang diberi garis warna kuning adalah section sungai yang sudah ada data ukurnya dari titik P0 sampai P100 (muara) yaitu sepanjang 3,7 km.

7. Pada DAS Remu yang diberi warna kuning tersebut berdasarkan data yang ada , terjadi masalah banjir dikarenakan secara topografi sudah berada di daerah flat (datar).

8. Daerah muara merupakan daerah alluvial (pengendapan sedimen dari hulu) sehingga secara teknis meningkatkan potensi banjir akibat pendangkalan muara dan pengaruh pasang surut air laut.

9. Terdapat beberapa titik yang berpotensi dijadikan lokasi site bandungan dalam rangka untuk mengoptimalkan pengendalian banjir.

\subsection{Analisa Kondisi Hidrometri DAS Remu}

Berdasarkan data dari stasiun Meteorologi Bandara DEO Kota Sorong Tahun 2007-2008, kondisi hidrologi Kota Sorong adalah sebagai berikut :

1. Curah hujan merata sepanjang tahun, dengan banyaknya hari hujan adalah 12 27 hari per bulan.

2. Tinggi curah hujan harian maksimum adalah $1028 \mathrm{~mm}$ dengan rata-rata 369 $\mathrm{mm} / \mathrm{bulan}$

3. Intensitas hujan untuk kala ulang 2 tahun adalah sekitar $9,4 \mathrm{~mm} / \mathrm{menit}$, yang dapat diartikan sebagai curah hujan dengan derajat hujan sangat deras (Sosrodarsono dan Takeda,2003)

Perkiraan sifat musim hujan di wilayah Kota Sorong adalah di atas normal dan curah hujan tinggi sepanjang tahun dengan prakiraan curah hujan komulatifnya pada periode Oktober 2008 - Maret 2009 adalah sebesar 1500-2000 $\mathbf{~ m m}$ atau rata-rata 250330 mm/bulan. (BMG Pusat, 2008) 
Dari gambar 1 terlihat kondisi daerah aliran sungainya menurut Soewarno (1991) :

1. Pola aliran sungai Remu adalah Dendritik, yaitu pola aliran sungai pada daerah dengan batuan sejenis yang penyebarannya luas, serta ditutupi oleh endapan sedimen yang luas dan terletak di daerah datar.

2. Indeks Kerapatan Sungai adalah 0,6 $\mathbf{k m} / \mathbf{k m}^{2}$ berarti termasuk kategori sedang, yang dapat diperkirakan sungai tersebut mempunyai gejala aliran sebagai berikut :

a. Alur sungai melewati batuan dengan resistensi relatif keras, sehingga angkutan sedimen akibat erosi yang berproses secara alamiah alamiah relatif kecil

b. Alur sungai melewati batuan yang tidak kedap air, sehingga air hujan yang jatuh pada DAS tersebut secara alamiah relatif kecil yang menjadi aliran permukaan.

Secara umum, ketersediaan data dan peralatan untuk mendapatkan data hidrometri DAS Remu sangat kurang, karena fakta dilapangan menyebutkan bahwa :

1. Tidak ada pos duga air untuk pengukuran debit sungai di sepanjang DAS Remu

2. Instansi terkait khususnya Dinas Pekerjaan Umum Kota Sorong tidak mempunyai peralatan pengukur tingkat sedimentasi DAS Remu

3. Hanya terdapat satu stasiun pencatat curah hujan di DAS Remu yaitu berada di Bandara DEO Kota Sorong, tepatnya pada bagian muara sungai Remu, dan baru mulai beroperasi pada tahun 2007 .

\subsection{Rencana Bendungan Sungai Remu}

Tujuan utama pembangunan bendungan Sungai Remu adalah untuk pengendalian banjir dan pemenuhan kebutuhan air bersih.

\section{Alternatif I : Optimalisasi tampungan rencana bendungan dengan mempertimbangkan kondisi kontur daerah aliran sungai, didapat $h_{\text {optimum }}=20$ meter.}

Gambar 2 di bawah ini memperlihatkan simulasi pemilihan lokasi site bendungan dengan cara mengolah peta SRTM Kota Sorong dengan software Global Mapper untuk memprediksi luas genangan di cathment area Rencana Bendungan Sungai Remu.

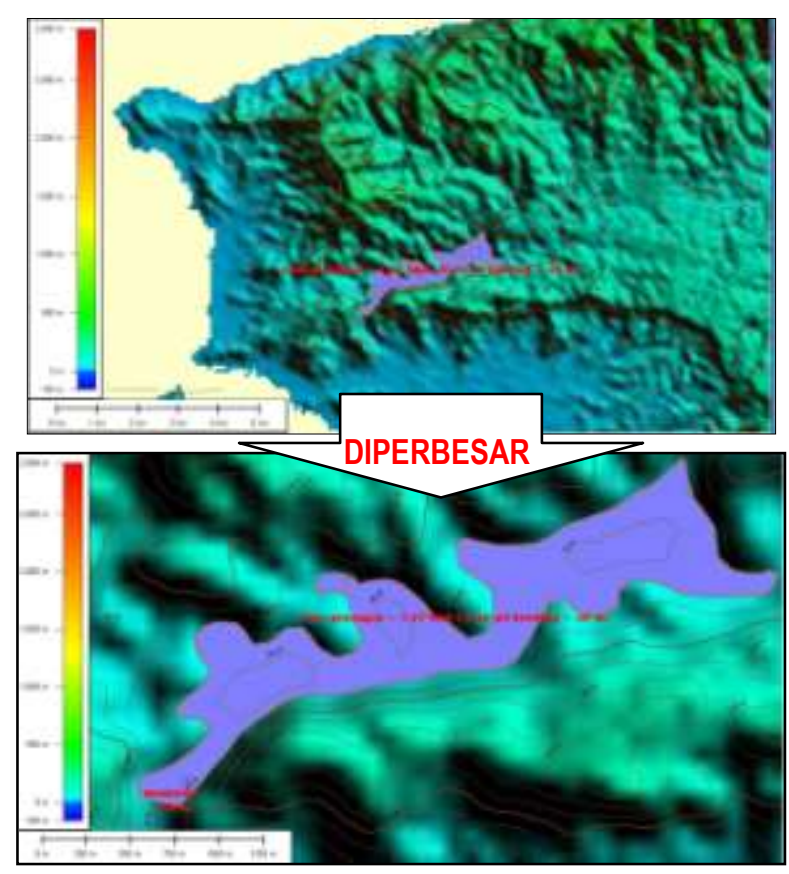

Gambar 2. Prediksi Luas Genangan

Dari hasil simulasi tersebut didapatkan prediksi data-data fisik pada rencana site bendungan Sungai Remu yaitu :

1. Panjang spillway optimum bendungan $=$ $234 \mathrm{~m}$

2. Tinggi crest spillway optimum $=20$ meter

3. Luas genangan optimum yang terjadi $=1,67$ $\mathrm{km}^{2}$

4. Volume air optimum yang bisa tertampung $=33.400 .000 \mathrm{~m}^{3}$

Dengan data fisik bangunan seperti di atas, maka rencana bangunan ini termasuk type bendungan besar menurut Soedibyo (1993).

Kelebihan alternatif I ini adalah

1. tersedianya volume tampungan air yang sangat besar, sehingga :

a. dapat menyuplai kebutuhan PDAM,

b. dapat memperbesar infiltrasi, sehingga volume Air Tanah di Kota Sorong yang berkualitas dapat terpenuhi dan untuk proteksi 
terhadap kemungkinan intrusi air laut (perlu penelitian khusus).

2. dapat dioptimalkan untuk pembangkit listrik mikrohidro

3. sistem pengendalian banjir dapat dimaksimalkan dengan pengaturan pintu air pada bendungan

4. bisa untuk pengembangan sektor wisata dan perikanan

Kekurangan alternatif I ini adalah :

1. biaya konstruksi mahal karena dimensi bangunannya yang besar.

2. Ketika intensitas hujan menurun sampai pada kondisi rendah, dikhawatirkan based flow sungai tidak dapat mengalir di daerah hilir sampai muara, karena sudah tereduksi di bendungan.

Konsekuensi dari alternatif I dalam operasional membutuhkan tenaga ahli dalam pengawasan keamanan bendungan dan dalam pengelolaan pembangkit listrik tenaga mikrohidro.

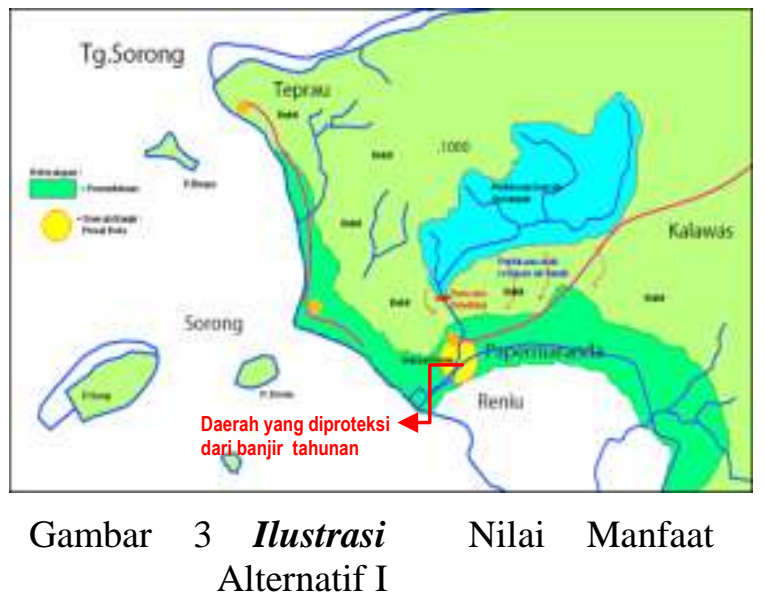

Alternatif II : Desain DAM seri, untuk meminimalkan tinggi bangunan sehingga diasumsikan lebih rendah biaya konstruksinya.

Pada alternatif ini diuraikan suatu konsep yang mengedepankan proses pengendalian banjir dengan membangun dam-dam (bending-bendung) kecil di beberapa ruas sungai Remu. Banjir dari hulu direduksi kuantitas debit maksimalnya, energy, dan kecepatanya oleh bangunan dam yang disusun secara seri. Harapanya, aliran sungai yang sampai di daerah -daerah langganan banjir seperti Kampung Pisang - Polres - Pasar Bersama - belakang Pasar Remu, sudah terkendali debitnya dan pada saat intensitas hujan rendah, based flow sungainya masih dapat mengalir.

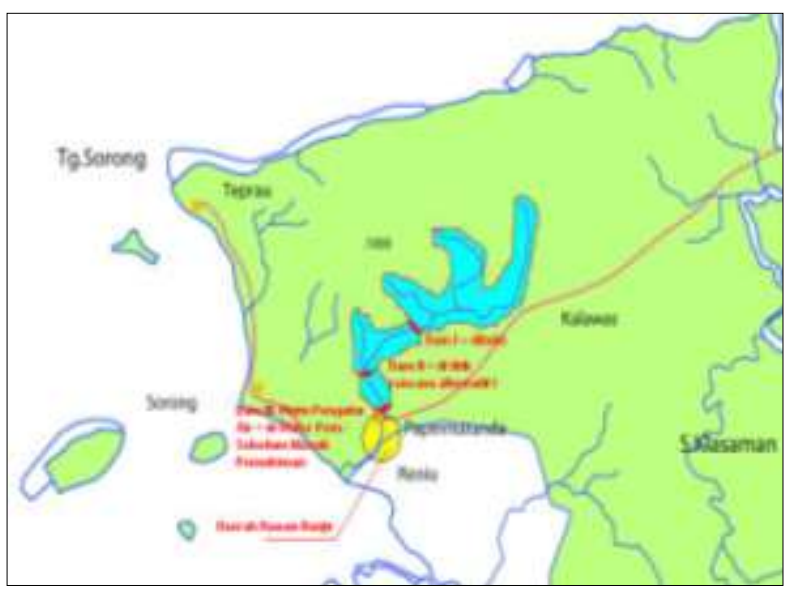

Gambar 4. Ilustrasi Alternatif II dengan membuat 3 Dam yang disusun seri sepanjang alur sungai , yaitu :

1. $\quad$ Dam $\mathbf{I}=$ di daerah pertemuan anak sungai di bagian akhir hulu sungai; berupa pelimpah (spillway) dengan pintu pembilas samping

2. Dam II = di titik rencana site bendungan ALTERNATIF I, berupa pelimpah (spillway) dengan pintu pembilas samping

3. Dam III = di daerah waterpom ; berupa spillway di lengkapi pintu pengendali muka air banjir dan pintu intake air bersih PDAM.

Tinggi dam yang disesuaikan dengan kondisi topografi masing-masing lokasi, yang diasumsikan sekitar 3 meter

Kelebihan alternatif II ini adalah

1. tersedianya volume tampungan air yang cukup untuk menyuplai kebutuhan PDAM,

2. biaya konstruksi relatif lebih rendah dibandingkan dengan alternatif I

3. debit banjir dapat direduksi secara bertahap, sehingga usia guna DAM lebih bisa dioptimalkan (meminimalisasi potensi DAM jebol oleh banjir)

4. Based flow sungai terjaga sepanjang alir sungai. 
ISSN $1979-7450$

Kekurangan alternatif II ini adalah :

1. Membutuhkan tenaga yang bekerja secara manual dalam operasional pintu air, khususnya pada saat debit banjir meningkat.

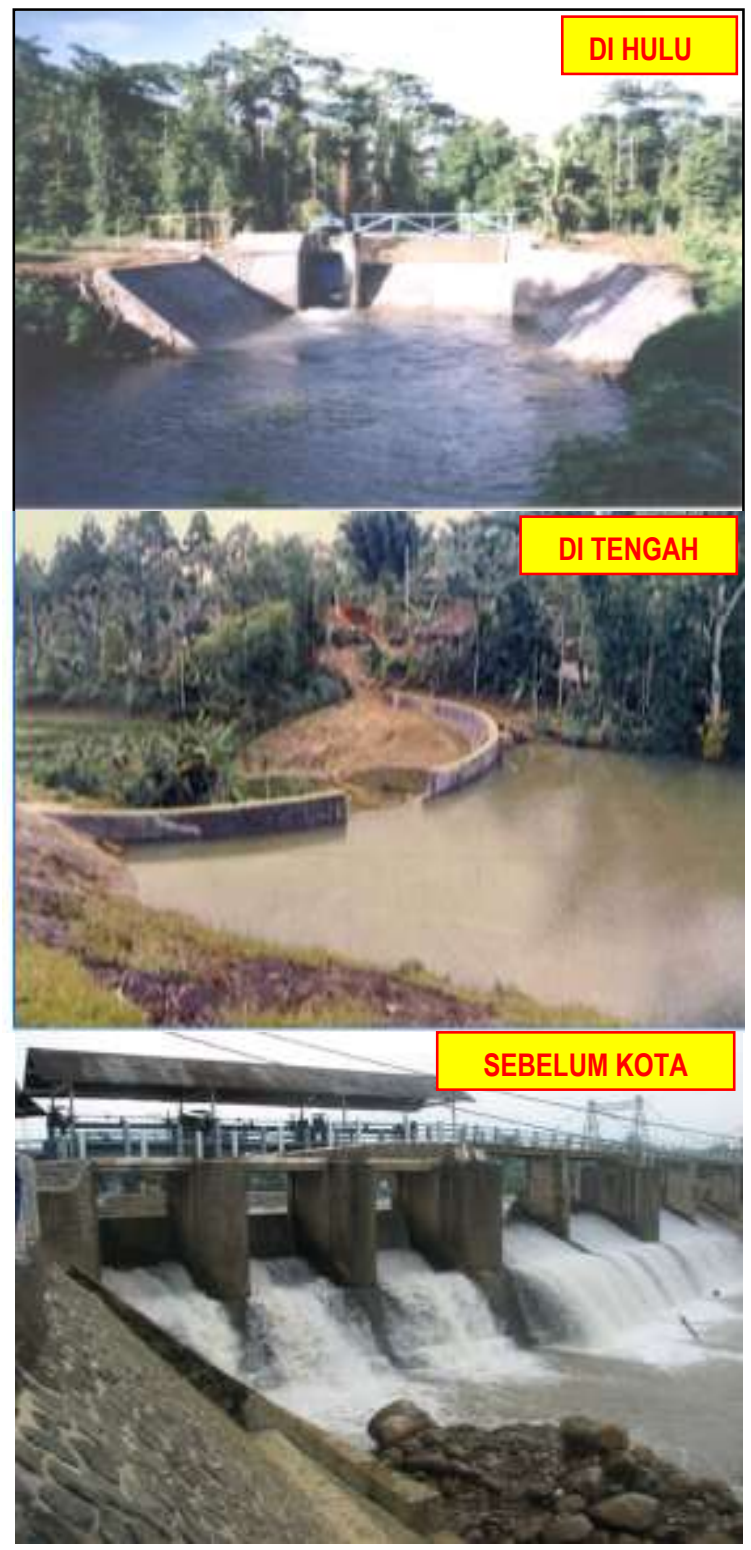

Gambar 5. Beberapa alternatif bentuk DAM seri

\subsection{Rencana/Desain Yang Terdapat dalam RTRW Kota Sorong Taun 2007-2012}

Diperkirakan wilayah genangan air pada bendungan yang akan dibuat mempunyai luas mencapai $5 \mathrm{Ha}$, dengan ketinggian air rata-rata yang dapat ditampung sekitar 10 meter. Bila kondisi ini dapat terwujud diharapkan debit air yang dapat ditampung oleh bendungan ini mencapai $500.000 \mathrm{~m}^{3}$. Debit air yang cukup besar ini dapat dijadikan sebagai sumber air baku oleh PDAM dengan kapasitas produksi mencapai $500 \mathrm{lt} / \mathrm{dt}$ hingga $1.000 \mathrm{lt} / \mathrm{dt}$.

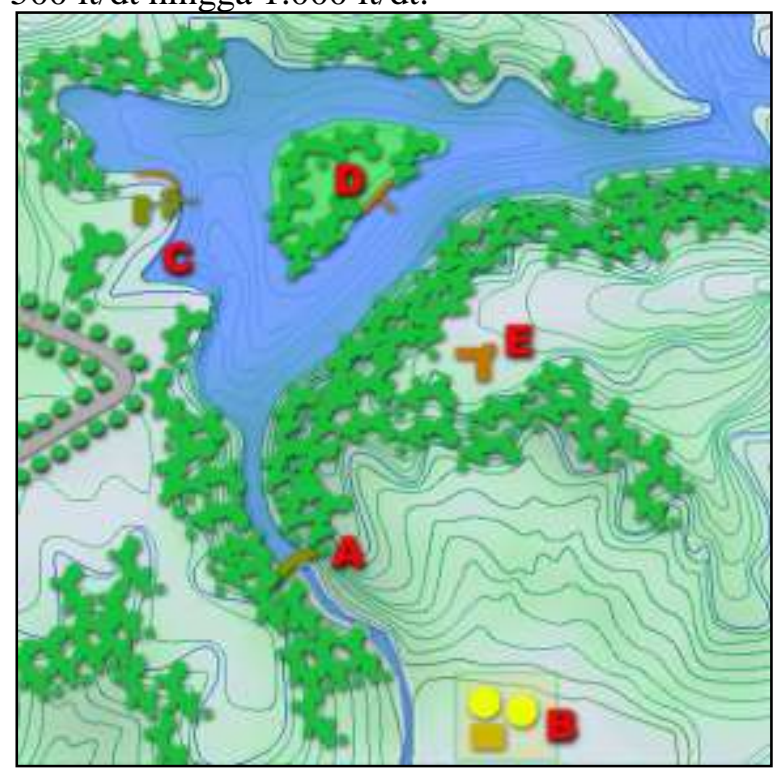

Gambar 6. Ilustrasi Rencana Pemanfaatan Potensi Bendungan Sungai Remu (A = spillway sebagai fungsi tampungan; $\mathrm{B}=$ Instalasi Pengolah Air Bersih PDAM ; C \& D = Wisata $\&$ Olahraga Air $; \mathrm{E}=$ Wisata Agro)

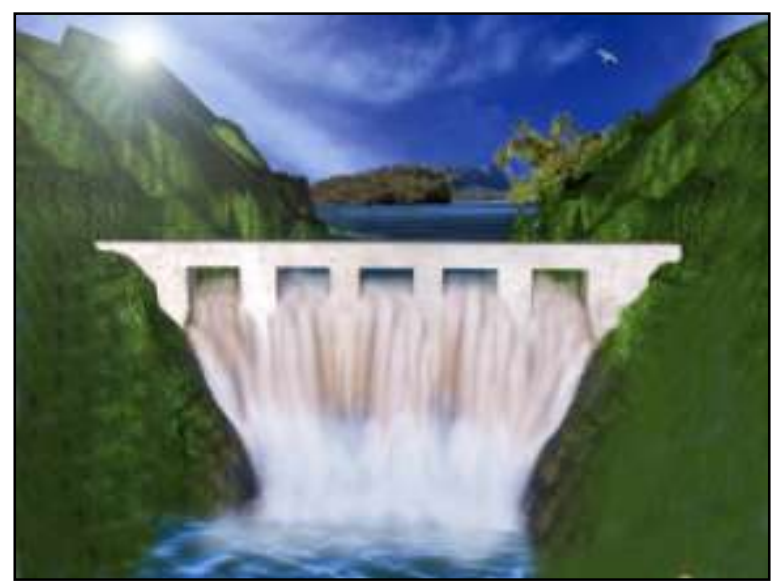

Gambar 7. Ilustrasi Bendungan Sungai Remu

(Sumber : RTRW Kota Sorong 2007-2012)

Kekurangan dan kelebihan point 5) ini hampir sama dengan ALTERNATIF I pada point 4). 
ISSN $1979-7450$

\section{PEMBAHASAN}

Dengan memperhatikan kelemahan dan kekurangan masing-masing alternative, maka dapat dibuat suatu rekomendasi yaitu :

1. Alternatif I membutuhkan biaya konstruksi yang paling besar, meskipun nilai gunanya juga sangat besar. Dibutuhkan kajian dari berbagai aspek untuk mewujudkan alternative ini, seperti aspek penanganan masalah sumber daya air di upstream dan down stream bendungan, aspek investasi, aspek AMDAL, aspek sosial, masalah pelepasan tanah adat dan peran serta masyarakat adat dalam mengelola bendungan tersebut.

2. Alternatif II, paling memungkinkan untuk dilaksanakan, karena selain biaya konstruksinya lebih rendah dibandingkang alternatif yang lain, pembangunan DAM secara seri juga telah banyak dilaksanakan di beberapa tempat, khususnya untuk mengelola banjir dan kekurangan air bersih untuk jangka pendek. Alternatif ini untuk jangka panjang harus ditinjau terkait dengan perkembangan dan perubahan tata guna lahan kota yang mempersempit ruang tampungan DAM yang paling dekat dengan pemukiman. Sehingga daerah antara DAM II dan DAM III lambat laun potensi banjirnya akan meningkat.

3. Alternatif yang sesuai dengan RTRW Kota Sorong, membutuhkan biaya yang besar dan kajian secara komprehensif sebagaimana ALTERNATIF I. Disini juga terlihat KINERJA Pemerintah Kota Sorong dalam mengimplementasikan apa yang tertuang dalam RTRW juga belum optimal. Hal ini terbukti bahwa sampai tahun 2009 rencana pengembangan strategis bendungan Sungai Remu ini yang belum mulai dilaksanakan.

\section{PENUTUP}

\section{Kesimpulan}

Kesimpulan yang dapat diambil dari uraian makalah ini adalah :

a. Pembanguan Bendungan Sungai Remu baik ALTERNATIF I dan ALTERNATIF yang sesuai dengan RTRW Kota Sorong, secara teknis layak dilaksanakan akan tetapi biaya konstruksinya besar. Ada kecenderungan pemerintah pusat melalui instansi terkait sudah mulai menghentikan pembangunan bendungan-bendungan skala besar.

b. Alternatif II yaitu Pembangunan DAM seri atau bertingkat, lebih layak untuk dilaksanakan karena dinilai lebih rendah biaya konsruksinya dibandingkan alternatif yang lainnya. Secara teknis alternatif ini juga bisa mereduksi banjir yang akan masuk wilayah pemukiman, dan juga bisa dioptimalkan untuk mensupley intake waterpom PDAM Kota Sorong.

c. Diperlukan perhatian pemerintah Kota Sorong dalam penanganan yang terintegrasi terhadap Sungai Remu dalam kaitannya dengan pengendalian banjir dan pemenuhan kebutuhan air bersih, karena di saat kota ini merupakan kota dengan curah hujan yang melimpah, terjadi dua fenomena yang bertolak belakang yaitu banjir dan kekurangan pasokan air bersih serta rendahnya kuantitas dan kualitas air tanah.

d. Konsep penanganan wilayah sungai sekarang pendekatanya adalah ekohidrolik pembangunan dan pegembangan sungai, dimana pendekatan fisik secara ekstrim pada DAS mulai ditinggalkan dan juga dikedepankan prinsip bagaimana menahan air seoptimal mungkin di wilayah DAS sehingga akan memperbesar proses infiltrasi untuk membantu mengelola kuantitas dan kualitas air tanah kita. 
ISSN 1979-7450

\section{Saran}

Untuk menindaklanjuti kelayakan alternatif bendungan atau DAM pada Sungai Remu, maka kami merumuskan beberapa saran dan rekomendasi untuk :

\section{a. BMG Kota Sorong}

- Perlunya ditambah instalasi pengukur curah hujan disepanjang aliran sungai Remu untuk mempermudah analisa hidrologi dalam pengembangan potensi sumber daya air Sungai Remu. (Minimal 1 unit di bagian hulu, 1 unit di daerah Waterpom/Kampung Pisang)

\section{b. Dinas PU Kota Sorong}

- Perlunya dibentuk satu unit khusus yang tugasnya mengelola dan menangani Sungai Remu secara terinegrasi dari hulu sampai hilir

- Perlunya pengadaan instalasi pengukur debit sungai, ini penting sekali untuk mengetahui rekam data fluktuasi debit sungai Remu dari waktu ke waktu sehingga akan memudahkan proses kajian dan analisa berkala terhadap kejadian banjir di Kota Sorong.

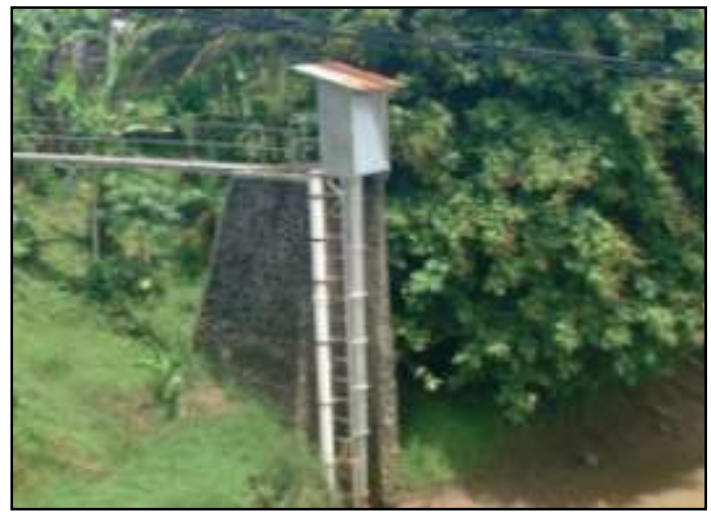

Gambar 8 . Contoh Instalasi Pos Duga Air .

- Perlunya survey / pengukuran topografi secara berkala dalam rangka untuk :

1. Rekam data cross dan long section sungai dari hulu sampai hilir, (data penampang sungai) secara periodik. Untuk saat ini baru bagian hilir yag sudah ada data ukurnya. Itupun seharusnya sudah disurvey ulang untuk mengetahui dinamika penampang sungai.

2. Pemetaan tinggi banjir dan luas genangan pada setiap kejadian banjir. Yang dilanjutkan dengan pemasangan patok peil banjir pada titik-titik tertentu, patokan dalam pendirian bangunan permanen di sekitarnya.

\section{c. Pemerintah Kota Sorong}

- Perlunya rumusan yang jelas dan terukur mengenai konsep pengendalian banjir ,pemenuhan kebutuhan air bersih dan proteksi terhadap kuantitas dan kualitas air tanah di Kota Sorong.

- Berkaitan dengan RTRW Kota Sorong tahun 2007 - 2012, khususnya mengenai rencana pembangunan bendungan di Sungai Remu sebagai bangunan pengendali banjir dan sebagai fungsi tampungan air bersih, diharapkan PEMKOT SORONG segera mengambil langkah nyata.

- Perlunya dilibatkan pihak akademisi di Kota Sorong dalam menyusun Pola pengembangan sumber daya air Sungai Remu dan Pola Penanganan Sumber daya Air Sungai Remu yang berkelanjutan dan terintegrasi dari hulu sampai hilir.

d. Akademisi Pendidikan Tinggi di Kota Sorong, dari tema ini masih diperlukan penelitian lebih lanjut mengenai :

- ASPEK TEKNIS :

1. Kajian Kondisi Hidrometri dan Topografi Hulu Sungai Remu

2. Kajian Sifat Fisik-Daya Dukung Tanah dan Formasi Batuan di sekita rencana bendungan / Dam

3. Kajian Perubahan Tutupan Lahan DAS Remu dari Hulu Hilir dalam kaitannya dengan Aliran Permukaan yang akan terkonversi menjadi debit banjir pada sungai Remu

4. Pemetaan Luas Genangan Banjir DAS Remu Kota Sorong 
5. Estimasi Kebutuhan Air Bersih Total Bagi Masyarakat Kota Sorong dalam kaitannya untuk desain ideal intake PDAM Kota Sorong

6. Potensi Pengembangan Sektor Pertanian dan Perikanan dengan rencana dibangunkan bendungan / Dam Sungai Remu

- ASPEK NON TEKNIS :

1. Kajian Kesiapan Masyarakat Adat / Lokal untuk menerima dan berpartisipasi dalam rencana pembangunan bendungan/dam Sungai Remu

2. Pengaruh Bendungan / Dam Sungai Remu dalam meningkatkan perekonomian Kota Sorong

3. Prespektif Masyarakat Kota Sorong Terhadap Potensi Bendungan / Dam Sungai Remu sebagai alternatif wisata danau air tawar di Kota Sorong

4. Prespektif Masyarakat Kota Sorong Terhadap Banjir Tahunan Sungai Remu dan Krisis Air Bersih pada durasi waktu yang bersamaan.

\section{DAFTAR PUSTAKA}

1. Anonym, (2008). Kota Sorong Dalam Angka Tahun 2008, Badan Pusat Statitik Kota Sorong.

2. Anonym, (2007). Rencana Tata Ruang Wilayah (RTRW) Kota Sorong Tahun 2007 - 2012, Pemerintah Kota Sorong.

3. $\_$Peta Rupa Bumi Kota Sorong dalam format SRTM http://hypersphere.telascience.org/el evation/cgiar srtm v4/ascii/zip/srtm 63 13.ZIP. Didownload pada tanggal 22 April 2009.

4. ,Ikhtisar Prakiraan Musim
Hujan di Indonesia Tahun 2008/2009. BMG Pusat, Jakarta. http://iklim.bmg.go.id/ikthprak0809. pdf. Didownload pada tahun 2008.
5. Sosrodarsono, S dan Takeda, K. (1999). Hidrologi untuk Pengairan. PT Pradnya Paramita. Jakarta.

6. Soewarno. (1991). Hidrologi Pengukuran dan Pengolahan Data Aliran Sungai. Nova. Bandung.

7. Maryono, A. (2005). Eko-Hidraulik Pembangunan Sungai. Magister Sistem Teknik PPS Universitas Gadjah Mada Yogyakarta.

8. Suripin,(2004). Sistem Drainase Perkotaan Yang Berkelanjutan, Penerbit Andi, Yogyakarta.

9. Soedibyo, (1993). Teknik Bendungan. PT Pradnya Paramita. Jakarta. 